\title{
Anthós
}

\section{Galen's Analogy: Animal Experimentation and Anatomy in the Second Century C.E.}

Annastasia Conner

Portland State University

Follow this and additional works at: https://pdxscholar.library.pdx.edu/anthos

Part of the History of Science, Technology, and Medicine Commons Let us know how access to this document benefits you.

\section{Recommended Citation}

Conner, Annastasia (2017) "Galen's Analogy: Animal Experimentation and Anatomy in the Second Century C.E.," Anthós: Vol. 8: Iss. 1, Article 9.

https://doi.org/10.15760/anthos.2017.118

This open access Article is distributed under the terms of the Creative Commons Attribution-NonCommercialShareAlike 4.0 International License (CC BY-NC-SA 4.0). All documents in PDXScholar should meet accessibility standards. If we can make this document more accessible to you, contact our team. 
Galen's Analogy:

Animal Experimentation and Anatomy

in the Second Century C.E.

Annastasia Conner

\section{Introduction and Historiography}

Galen of Pergamum (129 - ca. 216 C.E.) is truly one of the most pivotal characters in the history of medicine, and particularly the field of anatomy. A physician in the ancient Roman Empire, he did not allow his work to be constrained by contemporary boundaries, instead delving further into the field of anatomy and physiology than any doctor had yet done. He built upon the existing work of his predecessors as well as making new discoveries through which he would shape contemporary and future understandings of anatomy, and of medicine as a whole. Although a luminary in his field, Galen's work is not without need of serious consideration. His study of anatomy centered largely on the dissection of animals, and thus relied on the perceived physical similarities between animals and humans to apply his discoveries to the practical treatment of human patients. Doubtless this comparative method would have been less necessary had he been able to work with human bodies, but Galen never dissected a human corpse in his lifetime. ${ }^{83}$ His anatomical knowledge

\footnotetext{
${ }^{83}$ Scholars have debated this based on a few casual remarks scattered within his corpus, but more recent scholarship agrees that this is something he never actually achieved, regardless of the knowledge of human anatomy that he did clearly possess. Charles Singer wrote in his introduction to Galen's On Anatomical Procedures (Oxford: Oxford University Press, 1956), xxii, that he believed Galen to have dissected human bodies, but the more recent scholars that I have read do not share this view, namely: T.V.N. Persaud, Early History of Human Anatomy: From 118
} 
was gained through other methods, which will be discussed in more detail later in this paper.

The field of Roman medical history is vast, encompassing everything from more general, overarching works to specific case studies of Roman physicians and practices. On the more general end of the spectrum, we can observe scholars attempting to present the entire subject to a non-specialist reader, and to illustrate how the Roman people thought about medicine, as opposed to how physicians did. ${ }^{84}$ Scholars in the field have also pursued more specialized routes, including the consideration of Galen's views on the contemporary medical field, and specifically the differing medical sects at the time. ${ }^{85}$ Galen often set himself apart from these sects and from his peers, and this is of great interest to the discourse community of medical history. One historian portrays Galen as set apart based on the belief that his passion was inspired by and focused on his patients rather than based on his contributions to the medical field. ${ }^{86}$ This gives us some insight into how an ancient physician is perceived by modern scholarship, which may reflect the public perception of him during his own lifetime.

Arising out of a period from which our source material is sparse and unreliable, Galen's own written work is extensive and far-

Antiquity to the Beginning of the Modern Era (Springfield, IL: Charles C. Thomas Publisher: 1984), 60. All citations from On Anatomical Procedures will be from Singer's translation of the text.

${ }^{84}$ Ralph Jackson, Doctors and Diseases in the Roman Empire (London: British Museum Press, 1988).

${ }^{85}$ Christopher Cosans, "Galen's Critique of Rationalist and Empiricist Anatomy," Journal of the History of Biology 30 (Spring 1997): 36.

${ }^{86}$ Susan P. Mattern, The Prince of Medicine: Galen in the Roman Empire (Oxford: Oxford University Press, 2013). 
reaching. One historian argues that his prolific nature and eminence was due to his willingness to go far beyond the limitations of his teachers and his insistence on the fundamental need to dissect. ${ }^{87}$ As religious, medical, and social objections prevented human dissection, Galen performed his experiments on animals. ${ }^{88}$ No other contemporary physician took such strides, and it is for this reason, Nutton argues, that Galen has achieved such fame. Two physicians in Alexandria in the early third century B.C.E. practiced systematic human dissection, but these methods then disappeared completely from the ancient world and did not resurface again until the fourteenth century C.E. One scholar discusses this process in depth, exploring why this gap in human anatomical study occurred and the social, theological, and intellectual factors possibly involved. ${ }^{89}$

Galen is arguably best known for his anatomical discoveries, and historians have handled his experiments and the conclusions drawn from them in vastly different ways. One monograph discusses not only the technical and practical aspects of his animal dissections but the moral and ethical implications as well. The author examines the development of attitudes towards animal experimentation during the ancient period, when animals were widely believed to exist solely to serve human needs. ${ }^{90}$ The fundamental difference thought to

\footnotetext{
${ }^{87}$ Vivian Nutton, "Logic, Learning, and Experimental Medicine," Science, New Series 295 (February 2002): 801.

${ }^{88}$ Nutton, "Logic, Learning, and Experimental Medicine," 801.

${ }^{89}$ Heinrich Von Staden, "The Discovery of the Body: Human Dissection and Its Cultural Contexts in Ancient Greece," The Yale Journal of Biology and Medicine 65 (1992), 223.

${ }^{90}$ Anita Guerrini, Experimenting with Humans and Animals: From Galen to Animal Rights (Baltimore: Johns Hopkins University Press, 2003), 2. 
separate humans from animals was that animals possessed emotion, but not reason, and the author believes this idea to be in conflict with the analogy in use during this time, as Galen drew direct comparisons between human and animal anatomy. ${ }^{91}$ Other studies tend to be far more interested in the technical, scientific aspect of the anatomical demonstrations. ${ }^{92}$ The overall intent of one such work is to "provide a comprehensive study of the ways in which Galen sought to establish the brain as the regent part [...] of the body." 93 The author argues that Galen's experiments regarding the anatomy of the brain were all in the attempt to prove his thesis that the brain was responsible for the two defining qualities of the rational soul: sensation and voluntary motion. ${ }^{94}$ Although the field of Roman medicine is extensive, there are clearly a few scholars whose work stands out as being significant to this research.

This paper briefly discusses the early life and career of Galen of Pergamum and places him in the context of his field before examining the varying roles that animals played in the Roman Empire. It then explores Galen's use of these animals in his medical experiments in order to study the perceptions of these in Roman

\footnotetext{
${ }^{91}$ This idea of an 'analogy' of anatomy, which I will used throughout this paper, is a modern concept and comes from the secondary scholarship by Anita Guerrini. There is no evidence that the primary sources considered their methods through this lens, or using this terminology. Guerrini, Experimenting with Humans and Animals, $10-14$.

92 That being said, it should be noted that Rocca does briefly discuss the ethical question of human-animal comparison and the consideration of animals as nonrational beings. Julius Rocca, Galen on the Brain: Anatomical Knowledge and Physiological Speculation in the Second Century A.D. (Leiden; Boston: Brill, 2003), 70-71.

${ }_{93}$ Rocca, Galen on the Brain, xx.

${ }^{94}$ Rocca, Galen on the Brain, 239.
} 
society and his application of a human-animal analogy of anatomy, which allowed him to make more progress in this field than any other physician at this time. The use of this analogy, considered in relation to the 'prohibition' of human dissection, was absolutely necessary for the advancement of anatomical knowledge and the development of contemporary medical treatments.

\section{A Brief Introduction to Galen of Pergamum}

Early Life and Career

Galen was born in 129 C.E. in Pergamum, in modern day Turkey, which at the time was the Roman province of Ephesus. He was a student of philosophy before making the move towards medicine. However, as a young adult, he suffered a serious illness, which was cured, or so he believed, by the god of medicine, Asclepius. ${ }^{95}$ This personal miracle drove him to study medicine as "a servant of the ancestral god."96 The young physician spent time in Smyrna, then in Corinth, and later in Alexandria; he went back to Pergamum only after twelve years of medical study, a period exceptional in its length and setting him apart from other Greek and Roman physicians. ${ }^{97}$ Upon his return to Pergamum in 157 C.E., Galen became the surgeon to the gladiators there. This would have been a significant opportunity for him to observe the wounds of his patients and extend his knowledge of anatomy and physiology in this way. He traveled to Rome in 162, and by this time he was already "famed as a

\footnotetext{
95 Mattern, The Prince of Medicine, 26.

96 Galen, Libr. Propr. 2.19 (18-19K).

97 Jackson, Doctors and Diseases, 61. 122
} 
philosopher-physician," 98 which is certainly representative of the success he must have achieved in his work both within the gladiatorial arena, and without. "By 168, he became doctor to the emperor and held this position with successive emperors until his death." 99 It was during this period in Rome that Galen accomplished the work for which he is best recognized in medical history. The majority of his written corpus can be dated to this period, and this is also when he committed himself to the systematic dissection and vivisection of animal subjects as a method of learning about human anatomy.

\section{Galen in Context}

Acknowledging that Galen was not the only dedicated anatomist working in Rome at the time, and that his work was certainly not without faults, it is necessary to consider then, why historians study his work in such detail. Why is he the one who continues to be of such great importance, recognized as one of the fathers of human anatomy? In part, we have to take into account that Galen's work is important simply because it survived the passage of time. The scarcity of source material from the Roman Empire means that every source we have is extremely valuable. Perhaps Galen's works survived because he was the best, and his vast corpus was understood to be the last word in medicine, and perhaps it was due to the fact that he had powerful patrons who could have ensured that it was copied and kept. Regardless of why his works survived, they are

\footnotetext{
98 Jackson, Doctors and Diseases, 61.

${ }^{99}$ William H. York, Health and Wellness in Antiquity through the Middle Ages (Santa Barbara, CA: Greenwood, 2012), 24-25.
} 
useful to historians in many different ways. For the purpose of this paper, it is useful for us that Galen puts himself in context by discussing not only his predecessors, but also his peers. While his discussion of both groups is often heavily biased, it is still possible to develop an understanding of what the field of medicine entailed in Galen's time.

Galen's most influential predecessors were Herophilus of Alexandria and Erasistratus of Coes, a pair of physicians working in Alexandria in the early third century B.C.E. Unlike Galen or his contemporaries, these anatomists were given express permission from the king to carry out human dissections and vivisections using the bodies of condemned criminals. ${ }^{100}$ This was the first and last instance of human cadaver dissection in antiquity, and none of their work survives, except in references within Galen's writing. By the time Galen began practicing medicine, human dissection was no longer a viable option, although he did advise his students to visit Alexandria to view the human skeletons still available there for study. ${ }^{101}$ Taking into account that he was unable to perform human dissections, Galen still made more progress in the field than any other physician since Herophilus and Erasistratus. Galen was also highly influenced by Aristotelian philosophy regarding the rationality of animals, and by Hippocrates' notion of the four humours. He made a marked effort to disprove the anatomical discoveries of many of his predecessors, and indeed, of his peers.

\footnotetext{
100 The word 'king' is the choice of the author, used here to maintain consistency with the scholarship. Heinrich von Staden, Herophilus. The Art of Medicine in Early Alexandria (Cambridge: Cambridge University Press, 1989), 187-194.

101 Galen, Anat. Admin. 1.2 (221K).

124
} 
Galen was hardly the sole physician working in ancient Rome; he often refers to 'the anatomists,' which we can take to be his peers, based on the apparently coeval context of these references. These peers tended to fall within two major sects of study: Rationalist and Empiricist. These sects disputed the extent to which we are dependent on personal sense experience to gain knowledge; Rationalist thinkers advocate confidence in scientific theories, while Empiricists argue that practical experience of medical procedures is necessary. ${ }^{102}$ Galen criticized both groups and stressed that while the physician must explore the body for himself, "the best physician must both be acquainted with technical medical proceedings, and be well versed in philosophical and scientific thought."103

\section{Father of Anatomy: A Follow-Up Appointment}

While Galen made huge progress in the field of anatomy and contributed significantly to the development of medicine in antiquity, his method of comparative anatomy did not always lead to correct conclusions. Despite the obvious errors resulting from his dependence on animal dissection, his physical descriptions were meticulous and invaluable. It is important, however to recognize some of his failings. He subscribed to the Hippocratic belief that the uterus possessed two horns, even after viewing the uterine organs of various animals, but he also accurately described the cervix and ovaries. His descriptions of the brain and its functions were shockingly accurate, given that his

\footnotetext{
102 Christopher Cosans, "Galen's Critique of Rationalist and Empiricist Anatomy," Journal of the History of Biology 30 (Spring 1997): 36.

103 Cosans, “Galen's Critique," 37.
} 
research in this area was done almost exclusively on bovines. Likely one of his greatest failings is that he did not differentiate nerves from tendons, and failed to discover pulmonary circulation due to his "inadequate and distorted account of the blood vessels." 104 Due to the influential nature of his work in the field, this may have further delayed the eventual discovery of the processes of circulation by Galen's successors. Nevertheless, Galen's work was extremely influential to the development of the medical field, and it would have been quite impossible without those essential tools of his trade: the animal subjects of his experiments themselves.

Animals in Contemporary Roman Society: Altar, Arena, and Dissecting Table

Animals served humanity in a wide array of roles in the Roman Empire, but for this purpose of this paper, I will discuss only their roles within the following three categories: religion, entertainment, and medicine. These categories often intersect and interact with each other, no field being completely isolated from the others. The ultimate function of beasts in each role was to die, but the place and context of each death had the power to change the implications and, potentially, the propriety of the deed.

Animals were often used as sacrificial offerings in antiquity. A wide array of ceremonies required different formulas and words, but

\footnotetext{
104 Persaud, Early History of Human Anatomy, 63-64.
} 
the element of blood sacrifice remained the same. ${ }^{105}$ The offering of gifts of flesh to the gods was often an expression of thanks after a positive occurrence in a community or of pacifying an angry god, not as a method of asking for things. The death of the animal was a necessity, and while "slaying for sacrifice was naturally performed with solemnity proper for the occasion, [...] no significance was ever attached to the fact that the animal had died." 106 In Roman religion, the traditional victims were domesticated animals, such as pigs, sheep, and cattle. People consumed the sacrificial meat, and the gods were fed by the smoke created by the parts of the animal burned on the fire. ${ }^{107}$ Prayers always accompanied the ritual, as "without prayers the sacrifice is useless." 108 Pliny describes the prayers and structure of the ritual sacrifice as being extremely strict and exact, demanding precision in order to achieve the desired results. ${ }^{109}$ In the context of the sacrifice, animals are treated as objects, mere flesh with which one can make an appeal to the gods. The value of an animal in this situation is greater dead than it is alive, and it is in this evaluation that we can see the role animals played in religion in the Roman world.

Other than sacrifice, the most common use of animals in the Roman Empire was in the gladiatorial arena. These shows were put on to mark events, frequently the funerals of great men, and involved

\footnotetext{
105 Plin. HN. 28.3.10-12.

106 Royden Keith Yerkes, Sacrifice in Greek and Roman Religions and Early Judaism (New York: The Scribner Press, 1952), 5.

${ }^{107}$ Ingvild Sælid Gilhus, Animals, Gods and Humans: Changing attitudes to animals in Greek, Roman and early Christian ideas (London: Routledge, 2006), 115.

108 Plin. HN. 28.10.

${ }^{109}$ Plin. HN. 28.3.10
} 
various types of 'games.' Some involved the fighting of gladiators exclusively, and some forced condemned criminals to fight wild beasts. ${ }^{110}$ These events were public and spectacular, intended to entertain as well as to honor the dead. Over time the shows were decreasingly held in a funerary context, and increasingly for the amusement of the public. ${ }^{111}$ While sacrificial animals were more often domesticated, those used in the arena were commonly exotic as, "the whole world provided beasts for [the] shows."112 Most functions of animals in this period were characterized by the involvement of the public and a tendency towards exhibitionism.

Even in a medical setting, anatomical demonstrations were frequently used as an opportunity for entertainment. "The bloody, controlled violence of the vivisections, and their incontrovertible proof of man's mastery over animals, resembled the wild beast hunts so popular in the Roman arena-and especially in the capital city itself." 113 Galen often referred to the crowds observing his dissections as spectators, implying that they were expecting a spectacle, which he was always happy to provide. His dissection competitions with other anatomists also likely contributed to this perception of anatomical demonstrations as public entertainment. ${ }^{114}$

\footnotetext{
110 Plin. HN. 33.53.

${ }^{111}$ Hazel Dodge, "Amusing the Masses: Buildings for Entertainment and Leisure in the Roman World," Life, Death, and Entertainment in the Roman Empire, ed. by D.S. Potter and D.J. Mattingly, (Ann Arbor: The University of Michigan Press, 2010), 249.

112 Dodge, "Amusing the Masses," 332.

113 Mattern, The Prince of Medicine, 158.

114 Galen, Anat. Admin. 7.14 (636-637K). 128
} 


\section{The Human-Animal Analogy of Anatomy}

Rational Beings or "Non-Rational Brutes"115

Having discussed the place of animals in other areas of Roman society, we must also consider their place on the "scale of being,",116 particularly in the context of their relationship with human beings. While both man and animal were believed to possess souls, which were responsible for the ability to act, only humans were believed to possess reason. This meant that humans acted according to their reason, while animals acted according to nature, and were therefore lesser than rational men. ${ }^{117}$ Although this idea stems from Aristotelian philosophy, it was adopted and developed by the Stoics, who made it a central tenet in their texts on human and animal existence. By working within this philosophy, and by using it to his advantage, Galen built up his methods and discoveries around Stoic ideals. Animals were characterized as being fundamentally different from humans based on an innate aspect of human mental ability, and the varying ways in which animals were perceived and used in Roman society are based on this representation. Galen certainly embraced this idea of non-rationality, and used it liberally in the descriptions of his experiments, as follows: "It is surely more likely that a non-rational

\footnotetext{
115 Galen, Anat. Admin. 7.13 (632-33K).

116 Guerrini, Experimenting with Humans and Animals, 18.

117 Gilhus, Animals, Gods and Humans, 39.
} 
brute, being less sensitive than a human being, will suffer nothing from such a wound." 118

This statement displays a deeply entrenched contemporary understanding of animals to be without reason, and thus without pain, or at least not feeling pain to the same extent as human beings. Other physicians and intellectuals of this period had similar thoughts on the existence of animals, descending from the work and conclusions of Aristotle five centuries prior. Aristotle is one of the earliest recorded proponents of animal dissection, and many of his discoveries were highly influential upon anatomists in Galen's day. One of his most widely disseminated ideas, which served as the spine of much of Galen's experimentation, was that animals neither felt pain in the same way as humans, nor possessed anything like the same level of consciousness or capacity for independent thought. This precedent in the field allowed intellectuals at the time to compare the physical structures of animals to the human body while stating that animals exist for human use, are lacking rationality, and therefore fall far below humanity on the scale of being. ${ }^{119}$ This rather teleological view of nature reflects the general perception at the time that everything served a purpose in the natural order, which Galen adapted to create his working theory that every individual part of the human body had a purpose that together allowed for the functioning of the whole. ${ }^{120}$ Galen states not only that each anatomical part has its use, but also that each of his experiments and studies had its own specific purpose.

118 Galen, Anat. Admin. 7.13 (632-33K).

${ }^{119}$ Plin. HN. VII. This section discusses the existence of Nature, more broadly, creating all things for humanity's sake, and eventual use.

${ }^{120}$ Galen, Anat. Admin. 2.2 (286K). 130 
His teleological inclinations can be seen not just within his theories, but also in his physical dissections and the structure of his written works. Modern scholars have interpreted these tendencies on Galen's part to mean that he leaned towards the Aristotelian and Stoic view that animals, based on their natural role of serving man, had limited or no rationality. Again, this implies that they suffered less than humans, ${ }^{121}$ allowing Galen to select animals for dissection "that do not differ greatly in their [physical] nature from man."122 This suggests that, while these philosophical theories may have been common in this period, Galen may also have been consciously using them to suit his needs and excuse undoubtedly violent methods. "Because animals ranked far below humans on the scale of being, Galen followed Aristotle in granting to animals only limited consciousness, which implied considerably less consciousness of pain." 123

The Disuse of Human Dissection

The practice of dissecting human cadavers fell into disuse after the work done by Herophilus and Erasistratus, Galen's Alexandrian predecessors, in the third century B.C.E. These two scholars made many entirely new discoveries through the dissection of cadavers and the vivisection of condemned criminals, under the patronage of their benefactors, Ptolemy Soter and Ptolemy

${ }^{121}$ Rocca, Galen on the Brain, 70 (note 108).

122 Galen, Anat. Admin. 4.2 (423K).

${ }^{123}$ Guerrini, Experimenting with Humans and Animals, 18. 
Philadelphus. ${ }^{124}$ Celsus spoke of their work with disapproval, commenting that it is "superfluous [and] cruel as well, to cut into the belly and chest of men whilst still alive." ${ }^{125}$ He argued that the student could also learn better from the dead than the living, making vivisection needless. ${ }^{126}$ This statement shows us that physicians were not en masse against the dissection of cadavers, even those who were opposed to human vivisection. The lack of opposition, in fact, makes the disappearance of cadaveric dissection an even more mystifying conversation than previously thought. The only thing that seems to be definitively known is that there are no records of even a single case of human dissection between the work Herophilus and Eristratus in the third century B.C.E. and that of anatomists in the fourteenth century C.E., nor are there records of such prior to the Alexandrians. ${ }^{127}$ Even Alcmaeon of Croton, who worked in 500 B.C.E. and who serves as our first recorded instance of animal dissection in pursuit of anatomical knowledge, never moved beyond animals. ${ }^{128}$ This suggests that the Alexandrians were extraordinary in the history of anatomical research, outliers performing experiments that seemed to be considered universally unacceptable for a variety of reasons, most of which remained applicable for Galen and his contemporaries.

Galen does seem to imply that human dissections were still occurring in Alexandria by his time, by suggesting that his students visit in order to observe the human skeletons on display there:

\footnotetext{
${ }^{124}$ Persaud, Early History of Human Anatomy, 45.

125 Celsus, Med., proem 41.

${ }^{126}$ Celsus, Med., proem 42-43.

${ }^{127}$ Persaud, Early History of Human Anatomy, 45.

${ }^{128}$ Persaud, Early History of Human Anatomy, 29. 132
} 
Make it rather your serious endeavor not only to acquire accurate book-knowledge of each bone but also to examine [...] with your own eyes the human bones themselves. This is quite easy at Alexandria because the physicians there employ ocular demonstration in teaching osteology to students. For this reason, if for no other, try to visit Alexandria. ${ }^{129}$

I believe that this evidence suggests, however, that the study of these skeletons is so important because physicians were no longer able to gain knowledge of internal human anatomy from human cadavers, but solely from animals that somewhat resembled human beings. Therefore, these exposed skeletons were of much greater value to physicians, because they gave some pure knowledge of human anatomy that could be used in the process of animal comparison.

The question as to why this practice was discontinued has been one hotly debated by scholars in the field. Certain historians have made the vague statement that "the prohibition of human dissection by Rome in 150 BC arrested [Herophilus and Erasistratus'] progress and few of their findings survive."130 Others have used "forbidden,"131 and other similarly vague words to describe human dissection at the time. The more careful historian should consider the

129 Galen, Anat. Admin. 1.2 (221K).

${ }^{130}$ Emphasis added; Arthur C. Aufderheide, The Scientific Study of Mummies (Cambridge: Cambridge University Press, 2003), 5.

131 Persaud, Early History of Human Anatomy, 58. 
varying religious and sociological factors that likely contributed to the decline of human dissection by examining the Greek religious ideas of the pollution that accompanies death and the dying and the purification of those who have come in contact with them, ${ }^{132}$ the focus on hygiene and standards of cleanliness in urban areas, ${ }^{133}$ or the prominence within the field of a sect focusing on the theoretical study of medicine rather than the physical practice thereof. ${ }^{134}$ Another possibility is the growing focus on the religious concepts associated with burial. As one scholar wrote, "to leave a corpse unburied had unpleasant repercussions on the fate of the departed soul."135 This idea that lack of interment disturbs a soul's afterlife, in conjunction with that of corpse-based pollution, makes a compelling case for proper burial and the prevention of long-exposed or displayed corpses. These religious and sanitary concepts had already been relevant for centuries before Galen, which supports the idea that the Alexandrians were, indeed, outliers and that few contemporary or successive physicians would have had such freedom of study. ${ }^{136}$

Many factors were clearly at play in this period, all or some of which may have kept human dissection from serving as a viable option for Galen or his peers. Without solid evidence as to why this practice disappeared, the conversation is based on conjecture.

132 J.M.C. Toynbee, Death and Burial in the Roman World (Ithaca, NY: Cornell University Press, 1971), 42.

${ }^{133}$ All burials had to take place outside of the city, due to sanitary precautions. This was true until the late Empire, and even then exceptions were only made for emperors. Toynbee, Death and Burial, 48.

${ }^{134}$ Cosans, "Galen's Critique," 36.

135 Toynbee, Death and Burial, 43.

136 Toynbee, Death and Burial, 44. 134 
Although this is a hefty topic perhaps best suited for later extended research, it does seem apparent that, regardless of which factor was most responsible for the disappearance of this methodology, the stigma was strong enough to keep the practice from resurfacing until the fourteenth century.

\section{Application of Analogy to Human Treatment}

Given the dearth of human subjects, Galen dissected dogs, pigs, monkeys, apes, bears, and even one elephant. ${ }^{137}$ His writings contain extensive and precise anatomical descriptions of these animals and the step-by-step explanations of the procedures done upon them. His animal dissections were frequent and repetitive, and contributed to the ever-growing contemporary assumption "that the structure of man and animals, in particular apes and monkeys, was fundamentally the same." 138

The closest description that we have of a Galenic experiment being performed directly on a human subject was done on a slave, as a wound treatment procedure:

When the heart is exposed, your task is to preserve all its functions unimpaired, as in fact they are, so that you can see the animal breathing and uttering cries and, if loosed from its bonds, running as before. Further, if you continue to compress the

${ }^{137}$ Persaud, Early History of Human Anatomy, 60.

${ }^{138}$ Persaud, Early History of Human Anatomy, 60. 
wound with ligatures, you will see it taking food if hungry, and drinking if thirsty. And what is strange in that? The slave of Maryllus, the mime-writer, whose heart was once exposed, was cured and still lives. $^{139}$

While slaves were technically human, this passage implies that it was acceptable to test anatomical treatments on them, at the very least in situations of dire need. In this example, however, we can observe that the slave was experimented upon under the pretext of treating his injury (an injury serious enough that few likely thought him able to survive it), rather directly expressing the intent to learn from his exposed internal organs. In his animal experimentation, Galen draws comparisons between parts of the animal body and those of humans; these instances of direct comparison are important to note because his experiments are done with the intent of applying his anatomical knowledge to the treatment of human injury, as we can see described in the passage above. This treatment of injury method of learning human anatomy, as seen through the example of the slave, is as close as any anatomist after Herophilus and Erasistratus came to human dissection, making the method of comparative of anatomy an absolute necessity for progress towards improved wound treatment and patient care.

${ }^{139}$ Galen, Anat. Admin. 7.13 (632-33K). 136 
Although often asserting that the study of anatomy is best done through the dissection of humans, ${ }^{140}$ there is no evidence that Galen ever dissected one himself. Scholars have hotly debated this issue, discussing whether he could have actually drawn comparisons between human and animal anatomy with no knowledge of the former. I would argue that, rather, his experience with human anatomy appears to stem from the treatment of illness and deep, invasive wounds, as well as observation of corpses from a distance when he had the chance to do so, as described in the following passage:

On [one] occasion we saw the skeleton of a brigand, lying on rising ground a little off the road. He had been killed by some traveller repelling his attack. The inhabitants would not bury him, glad enough to see his body consumed by the birds which, in a couple of days, ate his flesh, leaving the skeleton as if for demonstration. ${ }^{141}$

Galen also reveals wounds to be the source of some of his knowledge, as, "extensive wounds and ulcers, reaching deep down, have exposed many parts which were recognized by the experienced as having the same structure as in the bodies of apes." ${ }^{142}$ Additionally, while none of their written work survives to the present day, Galen did have access to the research and discoveries of his Alexandrian

${ }^{140}$ Galen, Anat. Admin. 1.2 (224K).

${ }^{141}$ Galen, Anat. Admin. 1.2 (221-222K).

${ }^{142}$ Galen, Anat. Admin. 3.5 (386K). 
predecessors, and was likely able to learn a great deal about human physiological structures from this invaluable resource.

Knowledge of anatomical structures in the human body is crucial for the physician who must work with wounds and diseases of all varieties on a daily basis, and Galen believed that learning physical structures and procedures "is most necessary, and a really good physician must first of all have practice in it, and next in the actions of the inner organs, which are important for diagnosing diseases." ${ }^{143} \mathrm{He}$ preferred to work with apes because of their resemblance to man, although he did additional experiments on smaller animals with little to no resemblance for the purpose of proving "[his] conviction that each animal has a bodily structure akin to the character and powers of its soul." "144 In this way he confirms the separate notions of soul and reason, as discussed earlier in the philosophical theories of Aristotle. This both allows for the dissection of animals and creates a contradiction with the understanding that the physical is a representation of the mental. Assuming this is true, arguing the physical similarities of apes to humans should also imply closeness to reason, but Galen does not make this connection.

In his studies of the brain, Galen shied away from apes, and instead based his work largely on bovines, such as oxen, due to their size and availability. Size is important in that different aspects of anatomy are more apparent in larger animals, and the ox was the largest commonly available to him. Availability is a crucial factor in the work of an anatomist, especially one such as Galen, who would

\footnotetext{
143 Galen, Anat. Admin. 2.2 (287K).

${ }^{144}$ Galen, Anat. Admin. 6.1 (537-538K). 138
} 
complete the same procedures over and over in pursuit of perfection. He states that the ox brains that he preferred for dissections were usually for sale in large cities, and therefore were easily accessible. ${ }^{145}$ "It cannot be emphasized too strongly that Galen's anatomical work on the brain was carried out using the bovine as paradigm for the human brain." 146 Here, again, we see the analogy at work. The main focuses for Galen's study of the brain were the cranial bones and the dura, especially in regards to the ancient practice of trepanation and to develop treatment of skull fractures. ${ }^{147} \mathrm{We}$ can see the active pursuit of patient-treatment technique in his research goals. Given that trepanation (the practice of drilling holes in the skull in order to relieve pressure on the brain) was an extremely widespread technique at the time, the skull and brain were ideal teaching tools through which Galen was able to direct his students and create better physicians, directly influencing the effectiveness and safety of common medical practices in the Roman Empire.

Galen believed that the brain was the seat of the soul and reason in the human body, but that the voice and ability to utter sound were not related to reason. He completed experiments, therefore, on the loss of voice in certain animals based on the types of procedures performed. He concluded that the voice was not controlled by the brain, but rather by the intercostal muscles, as well as those of the respiratory system, stating that:

${ }^{145}$ Galen, Anat. Admin. 9.1 (708K).

${ }^{146}$ Rocca, Galen on the Brain, 69.

${ }^{147}$ Rocca, Galen on the Brain, 75. 
To be truly convinced that the power of both expiration and phonation is injured by the paralysis of the intercostal muscles, it suffices to destroy those below the shoulder blades, by severing their fibres $[\ldots]$ The proportion that those paralysed bear to all the intercostal muscles seems to determine how much of the whole natural power of expiration and of utterance is lost. ${ }^{148}$

In this way he was able to determine that the tortured cries of the subjects of his vivisections were neither rational nor sentient, thereby eliminating any moral or ethical objections to his experiments while still making discoveries regarding the source of the voice and its connections with the rest of the body. These discoveries were applicable to the physician's understanding of human anatomy and medical treatment regarding illnesses involving respiration or the voice, without compromising their ability to use animals for experimentation and anatomical comparison.

\section{Conclusion}

As a physician in antiquity specializing in human anatomy, Galen faced many obstacles, not least being the stigma against dissecting human corpses. His work therefore centered around the dissection and vivisection of animals in order to develop a method of comparative anatomy in which the physical structures of animals

\footnotetext{
148 Galen, Anat. Admin. 8.7 (685-690K). 140
} 
effectively became those of human beings within medical understanding. Through the examination of Galen's early life and career, the varying roles of animals in Roman society, and the development of the anatomical field through Galen's experiments, this paper has shown this human-animal analogy of anatomy to be necessary for the growth of medical knowledge and the development of treatments for human patients.

The use of this analogy was dependent on the conceptual separation of the physical similarities of animals and humans from the mental and emotional similarities. The Aristotelian philosophy that animals were non-rational and therefore did not feel pain in the same way as humans do was vital to the continuation of animal vivisection, without which a great deal of knowledge would never have been gained, as it eliminated the moral and ethical concerns connected with cutting into a living being. The rejection of sentience and physical sensitivity or perception allowed anatomists like Galen to use animals closest to man in their physical attributes without concerning themselves with their subjects' experience during the procedures.

The study of Galen and the development of comparative human anatomy is a field overrun with debates over every minute detail. Most relevant to the argument of this paper is the debate regarding why the practice of human dissection was discontinued before Galen's time and did not resurface until the fourteenth century. Some scholars have vaguely stated that human dissection was 'prohibited' or 'forbidden' without elaborating on this matter, while others have gone more in-depth into the examination of this medical 
development. This conversation is vital, as the disuse of this practice is one of the most eminent factors making comparative anatomy so necessary in antiquity.

Galen's written work displays excellent examples of the human-animal analogy at work in descriptions of both anatomical demonstrations and the treatment of human patients. The historian is able to track through his corpus how his discoveries were made, and then regularly applied to the practice of medicine. Two stunning examples are those of the experimental exposure of the heart of a living animal, which was later used as a last, and ultimately successful, attempt at saving the life of a slave; and the advancement of the practice of trepanation, a technique widely used in antiquity, which was greatly improved and corrected by Galen and his students. These examples assist in showing the way that comparative anatomy contributed to the development of medicine and patient treatment in the Roman Empire. The human-animal analogy of anatomy was invaluable in antiquity, furthering discoveries without which the field of medicine would at least have developed at a much slower pace throughout later history.

More research clearly needs to be done into the discontinuance of human dissection in the ancient world following the work of the scholars in Alexandria in the early third century B.C.E. It is not enough to simply state that human dissection was 'prohibited' in ancient Rome; the factors contributing to this phenomenon should be examined in greater detail. Future research should also be considered in the simultaneous or preceding development of anatomical knowledge and medical developments in this field in Eastern cultures. 
A comparison study in methods and animal usage could be useful in establishing a broader worldview regarding the development of anatomy in the ancient world.

\section{References}

Primary

Celsus. De Medicina. Translated by W.G. Spencer. London:

Heinemann, 1935.

Galen. De anatomicis administrationibus (On Anatomical

Procedures). Translated by Charles Singer. London: Oxford University Press, 1956.

------. On Anatomical Procedures, the Later Books. Translated by W.L.H. Duckworth. Cambridge: Cambridge University Press, 1962.

------. De libris propriis (On My Own Books). In Galen: Selected

Works. Translated by P.N. Singer. Oxford: Oxford University Press, 1997.

------. De animi cuiuslibet affectum et peccatorum dignotione et curatione (On Diagnosing and Curing the Affections and Errors of the Soul). In Galen: Selected Works. Translated by P.N. Singer. Oxford: Oxford University Press, 1997. ------. De naturalibus facultatibus (On the Natural Faculties).

Translated by A.J. Brock. Cambridge, MA: Harvard University Press, 1916.

Pliny, the Elder. Historia Naturalis (Natural History). Translated by H. Rackham. Cambridge, MA: Harvard University Press, 1949. 
Secondary

Aufderheide, Arthur C. The Scientific Study of Mummies. Cambridge: Cambridge University Press, 2003.

Cosans, Christopher E. “Galen's Critique of Rationalist and Empiricist Anatomy." Journal of the History of Biology 30 (1997): 35-54.

Dodge, Hazel. "Amusing the Masses: Buildings for Entertainment and Leisure in the Roman World." In Life, Death, and Entertainment in the Roman Empire, edited by D.S. Potter and D.J. Mattingly, 229-279. Ann Arbor: The University of Michigan Press, 2010.

Gilhus, Ingvild Sælid. "United by Soul or Divided by Reason?” Animals, Gods and Humans: Changing Attitudes to Animals in Greek, Roman and Early Christian Ideas. London: Routledge, 2006.

Gleason, Maud W. "Shock and Awe: The Performance Dimension of Galen's Anatomy Demonstrations." In Galen and the World of Knowledge, edited by Christopher Gill, Tim Whitmarsh, and

John Wilkins, 85-114. Cambridge: Cambridge University Press, 2009. Guerrini, Anita. Experimenting with Humans and Animals: From Galen to Animal Rights. Baltimore: Johns Hopkins University Press, 2003.

Jackson, Ralph. Doctors and Diseases in the Roman Empire. London: British Museum Press, 1988. Mattern, Susan. The Prince of Medicine. Oxford: Oxford University Press, 2013. 
Nutton, Vivian. "From Galen to Alexander, Aspects of Medicine and Medical Practice in Late Antiquity." Dumbarton Oaks Papers 38 (1984): 1-14.

-----. “Logic, Learning and Experimental Medicine.” Science, New Series 295 ](February 2002): 800-801.

Persaud, T.V.N. Early History of Human Anatomy: From Antiquity to the Beginning of the Modern Era. Springfield, IL: Charles C. Thomas Publisher: 1984.

Rocca, Julius. Galen on the Brain: Anatomical Knowledge and Physiological Speculation in the Second Century A.D. Leiden; Boston: Brill, 2003.

Toynbee, J.M.C. Death and Burial in the Roman World. Ithaca, NY: Cornell University Press, 1971.

Von Staden, Heinrich. "The Discovery of the Body: Human

Dissection and Its Cultural Contexts in Ancient Greece." The Yale Journal of Biology and Medicine 65 (1992): 223-241.

------. Herophilus. The Art of Medicine in Early Alexandria.

Cambridge: Cambridge University Press, 1989.

Yerkes, Royden Keith. Sacrifice in Greek and Roman Religions and

Early Judaism. New York: Charles Scribner's Sons, 1952.

York, William H. Health and Wellness in Antiquity through the

Middle Ages. Santa Barbara, CA: Greenwood, 2012. 